\title{
Penggunaan Mesin Pemotong Kerupuk Hemat Energi untuk Meningkatkan Produksi dan Kwalitas Kerupuk Rambak Singkong
}

\author{
Ir. Ali Mokhtar MT, $\quad$.1) Dr. Moch. Agus Kresno M.Kes .2)
}

\section{Ringkasan}

Kebutuhan akan kerupuk rambak sebagai sampingan lauk pauk meningkat pesat, seiring pertumbuhan penduduk. Pesanan kerupuk rambak tiap bulan mencapai 2 ton, Sedangkan UKM UD. KERUPUK ENAK hanya mampu memenuhi 50 sampai 60\% dari kebutuhan masyarakat. Produksi kerupuk rambak dengan proses manual dengan menggunakan 6 tenaga manusia hanya mampu memproduksi $40 \mathrm{~kg}$ tiap hari sehingga satu bulan hanya mampu memproduksi 1 ton. Produksi dengan menggunakan mesin pemotong dengan 2 orang tenaga manusia, mampu memproduksi $240 \mathrm{~kg}$ tiap hari, sehingga tiap bulan mampu memproduksi sampai 6 ton.

UD. KERUPUK ENAK berlokasi di Desa Druju No. 1 Kecamatan Sumbermanjing wetan, Kabupaten Malang dengan jarak dari Universitas Muhammadiyah Malang sekitar $50 \mathrm{~km}$ merupakan salah satu industri penghasil kerupuk telah berproduksi sejak tahun 2004. Kegiatan pemotongan kerupuk secara manual hanya mampu memberi penghasilan kotor Rp. 5.000.000,- tiap bulan, sedangkan dengan menggunakan mesin pemotong mampu meningkatkan penghasilkan sampai Rp. 30.000.000,- tiap bulan, sehingga dengan adanya mesin pemotong ini sangat membantu bagi UKM. UD. KERUPUK ENAK.

1). Staf Pengajar Fakultas Teknik

2.) Staf Pengajar Fakultas Ilmu Keguruan dan Pendidikan 
Ali Moehtar dkk. Penggunaan Mesin Pemotong Kerupuk Hemat

\section{A. PENDAHULUAN}

\section{Analisis Situasi}

Usaha kecil dan menengah pembuatan krupuk rambak UD Kerupuk Enak berada di Desa Druju Nomer 1 RT 01 RW 01 Kecamatan Sumbermanjing wetan Kabupaten Malang, merupakan salah satu dari beberapa industry kerupuk yang ada, industry ini mempunyai potensi yang bagus untuk berkembang mengingat letaknya yang strategis, dekat dengan jalan raya, serta dekat dengan bahan baku.

\section{Sumber Daya Manusia}

Usaha kecil dan menengah pembuatan kerupuk rambak singkong UD Kerupuk Enak berada di Desa Druju Nomer 1 RT.02 RW.01 Kecamatan Sumbermanjing Wetan Kabupaten Malang, Telp ( 0341) 8637790 dengan jarak dari kampus Universitas Muhammadiyah Malang 30 km, akses jalan baik dan lancar dengan waktu tempuh kurang dari 1 jam perjalanan. Sebagai pimpinan usaha Bapak Sumardi; bendahara Ibu Sumartik, tenaga kerja pembantu 4 orang terdiri dari 3 orang tenaga produksi dan 1 orang tenaga pemasaran, Fasilitas usaha terdiri dari gudang dan tempat proses produksi ukuran 4 x 6 meter dan 2 buah sepeda motor.

\section{Kondisi Manajemen dan Investasi}

Manajemen usaha yang dikelola sudah cukup baik, dimana Bapak Sumardi sebagai pemilik usaha sekaligus berperan sebagai manajer UD Kerupuk Enak. Kondisi manajemen sudah tertata dengan baik yang meliputi : pembagian kerja karyawan, pembukuan dan laporan
Energi

keuangan usaha. Selain memproduksi kerupuk rambak singkong, UD Kerupuk Enak juga memproduksi berbagai jenis kerupuk, hanya kapasitas produksinya relatif kecil yaitu 1 ton/bulan. Investasi meliputi : gudang usaha, kantor dan kendaraan pengangkut bahan.

Daerah pemasaran yang luas mencapai di wilayah Kecamatan Sumbermanjing, Kecamatan Turen, Kecamatan Dampit, Kecamatan Kepanjen Kabupaten Malang dan beberapa daerah di Kota Malang dan Kabupaten Blitar. Permintaan kerupuk rambat singkong mentah dalam setiap bulan mencapai 2 ton/ bulan tetapi hanya mampu mensuplai kerupuk rambak singkong sekitar 50 - 60\% dari kebutuhan.

\section{Kondisi Produksi}

Produksi kerupuk rambak singkong di UKM UD Kerupuk Enak hanya 1 ton/bulan, karena proses produksi yang masih mengandalkan tenaga manusia. Apabila ada kebutuhan kerupuk rambat singkong mentah yang mendesak, tidak dapat dipenuhi sesuai dengan permintaan.

Makna eksistensi industri/pengusaha kecil UD Kerupuk Enak terhadap lingkungannya telah dirasakan oleh masyarakat. Berkembangnya usaha UD Kerupuk Enak akan berdampak langsung dan positif terhadap pendidikan kecakapan hidup (life skllis) masyarakat sekitar termasuk para santri, dan juga memberikan peluang untuk bekerja, magang, dan membuka usaha baru manakala santri tersebut telah kembali ke daerahnya. 
Jurnal Dedikasi Volume 7, Mei 2010

\section{B. PERUMUSAN MASALAH}

\section{Permasalahan}

Permintaan kerupuk rambat singkong mentah dalam setiap bulan mencapai 2 ton/bulan tetapi hanya mampu mensuplai KERUPUK RAMBAK SINGKONG sekitar 50 - 60\% dari kebutuhan. Permasalah dalam industri kerupuk rambak singkong di UD Kerupuk Enak adalah rendahnya kapasitas produksi dikarenakan pencetakan kerupuk ramak singkong dengan tenaga manusia. Beberapa kelemahan apabila pencetakan kerupuk dengan tenaga manusia adalah kapasitas produksi rendah dimana untuk menghasilkan 1 ton kerupuk rambak mentah perlu 2 - 3 orang dengan waktu 1 bulan, kebutuhan kerupuk rambak mentah yang mendesak tidak bisa terpenuhi, kontinyuitas produksi tidak tercapai, hasil pencetaka tidak homogen dan kualitas produksi rendah (tingkat kontaminasi bakter/jamur) relatif tinggi sehingga membahayakan kesehatan konsumen.

\section{Rumusan Masalah}

Untuk mengatasi kendala tersebut, maka perlu merumuskan masalah yang ada sehingga diciptakanlah alat pencetak kerupuk rambak singkong dengan kapasitas 50 kg/jam, pada akhirnya dapat memenuhi kebutuhan konsumen. Keuntungan dengan penggunaan mesin pencetak atau mesin pemotong ini adalah kapasitas produksi dapat ditingkatkan menjadi 1,5 - 3 kwintal/hari atau sekitar 5-6 ton/bulan, kualitas kerupuk rambak singkong terjamin. Dengan demikian akan meningkatkan keuntungan sampai 300\%. Adapun Teknologi yang diterapkan berupa mesin pemotong hemat energi dapat dilihat pada Lampiran gambar dan foto kegiatan.

\section{Tinjauan Pustaka \\ Prospek Usaha Kerupuk}

Usaha kerupuk mertupakan jenis usaha yang prospektif. Mahyan misalnya, pengusaha kerupuk dari Ciputat, Jakarta Selatan, sudah melakukan usaha kerupuk pada 1982 silam. Jenis kerupuk yang diekspor ke negeri Kincir Angin itu, biasa saja. Sama seperti yang sering kita temui di rumah makan atau kedai mie bakso, yaitu yang berbentuk bulat dengan warna putih, dan yang berbentuk persegi empat dengan warna coklat. Tentu saja, yang diekspor adalah kerupuk mentah. Mahyan melakukan ekspor seminggu sekali, masing-masing sebanyak 4 kuintal. Selain Belanda, ia juga mengekspor kerupuknya ke Arab Saudi. erkat kegiatan ekspor itu, usaha kerupuk Mahyan meningkat pesat. Sehingga pada 1985, dia sampai mempekerjakan 130 karyawan. Sedangkan produksi kerupuknya, sehari menggunakan 6 kuintal tepung (Mitra Wacana, 2008-a).

Pasar di dalam negeri sendiri masih sangat besar. Sekarang ini, Mahyan masih memproduksi kerupuk sebanyak 2,5 kuintal sehari untuk pasar dalam negeri. Perusahaan kerupuknya sekarang ini juga lebih sehat karena telah menerapkan manajemen modern, yang dilakukan oleh seorang anaknya yang sudah jadi sarjana ekonomi. Sementara anaknya yang lain, yang juga sarjana, memiliki usaha kerupuk sendiri, yang jauh lebih besar dari perusahaan Mahyan. H. Mahyan, 
kenyataannya, hanyalah salah satu contoh dari sekian banyak pengusaha sukses yang menangguk banyak untung dari usaha kerupuk. H. Suganda, yang merintis usaha kerupuk pada 1982, sekarang sudah mampu memproduksi sebanyak 28 ribu biji kerupuk sehari. Produksi sebanyak itu, menghabiskan 4 kuintal tepung (Mitra Wacana, 2008-a).

Pengusaha lainnya, Samsuri, yang sebelumnya hanya sebagai penjual krupuk dengan gerobak, sekarang sudah memiliki pabrik sendiri yang produksi kerupuknya menghabiskan tepung antara 3,5 sampai 4 kuintal tepung. Pabrik milik Samsuri yang berlokasi di Tangerang tersebut, sejak setahun lalu dilengkapi mesin pencetak kerupuk yang dibeli seharga Rp 16 juta. Sedangkan karyawan yang membatunya sebanyak 15 orang. Melalui 30 orang pedagangnya, kerupuk Samsuri dipasarkan dengan merek SHD sama seperti merek punya Suganda ke daerah Depok, Parung, Senayan sampai Cinere. Masih di daerah Tangerang, tepatnya di Pamulang, Endi Suhendi juga tercatat sebagai pengusaha kerupuk yang sukses. Dia berhasil membeli sebuah pabrik kerupuk lengkap dengan peralatannya senilai Rp 20 juta. Dari pabrik itulah, setiap harinya menghabiskan tidak kurang dari 4 kuintal tepung untuk produksi kerupuknya Para produsen yang menghabiskan tepung dalam jumlah kuintalan, pada umumnya sudah menggunakan mesin khusus untuk membuat adonan dan mencetak kerupuk (Mitra Wacana, 2008-a).
Salah satu produksi mesin pencetak kerupuk kotak yang dihasilkan oleh PT Maksindo Malang mempunyai kapasitas 1-2 ton perhari, motor press 3/4 $\mathrm{Pk}$, konfeyer $1 / 4 \mathrm{PK}$, dan terbuat dari bahan besi (PT Toko Mesin Maksindo, 2008).

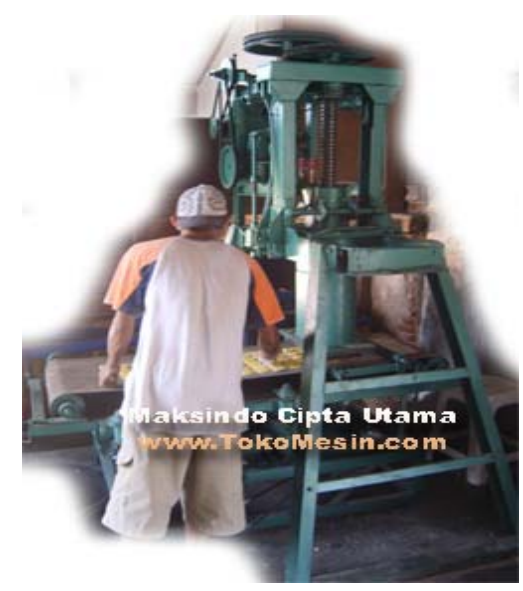

Gambar 3.1 Mesin Pencetak Kerupuk Kotak Produksi PT Maksindo Malang

2. Mesin Pencetak Kerupuk Mawar Salah satu produksi mesin pencetak kerupuk kotak yang dihasilkan oleh PT Maksindo Malang mempunyai kapasitas 1-2 kwintal perhari, motor press $3 / 4 \mathrm{PK}$, konfeyer $1 / 4 \mathrm{PK}$, terbuat dari bahan besi (PT Toko Mesin Maksindo, 2008). 
Jurnal Dedikasi Volume 7, Mei 2010

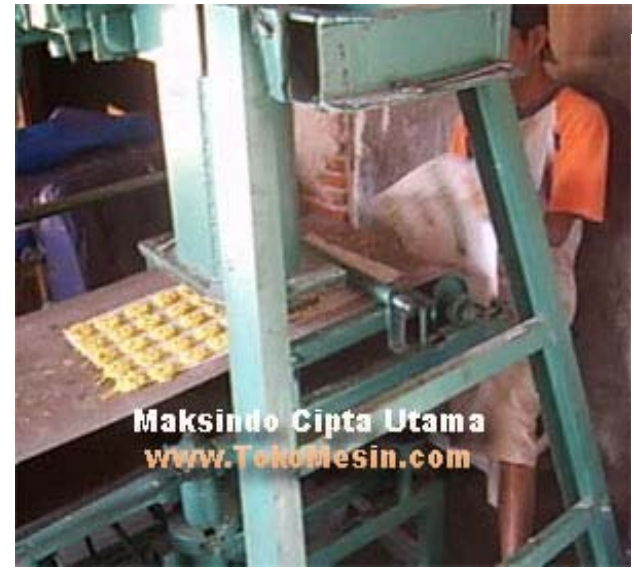

Gambar 3.2 Mesin Pencetak Kerupuk Mawar Produksi PT Maksindo Malang

\section{Tahapan Pengerjaan Mesin Pencetak Kerupuk Rambak Singkong}

Pengerjaan mesin pencetak kerupuk dilakukan dengan memperhatikan kaidah-kaidah proses pengerjaan logam, yang didalamnya meliputi : pengukuran, pemotongan, pembubutan, penggerindaan, pengeboran, penelasan dan terakhir perakitan antar bagian.

Secara keseluruhan dapat dilihat pada skema sebagai berikut :

\begin{tabular}{|ll|}
\hline & PERSIAPAN \\
\hline 1. & Persiapan bahan \\
2. & Persiapan peralatan \\
3. & Pengukuran \\
\hline
\end{tabular}

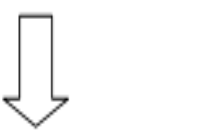

\begin{tabular}{|l|}
\hline \multicolumn{1}{|c|}{ PEMBUATAN } \\
\hline 1. Penggergajian \\
2. Pembubutan \\
3. Pengeboran \\
4. Pengelasan \\
5. Pengecatan \\
6. Perakitan \\
\hline
\end{tabular}

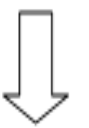

\begin{tabular}{|l|}
\hline \multicolumn{2}{|c|}{ KENDALI MUTU } \\
\hline 1. Memerikasa pekerjaan dan menguji coba fungsi dan \\
kapasitas alat \\
2. Merevisi alat bila dalam uji coba terdapat kekurangan. \\
\hline
\end{tabular}

Gambar 3.3 Tahapan Pengerjaan Mesin

Pencetak atau

Pemotong Kerupuk Rambak

Singkong 
Ali Moehtar akk. Penggunaan Mesin Pemotong Kerupuk Hemat

\subsection{Spesifikasi dan Mekanisme Kerja} Mesin

Mesin pencetak krupuk atau mesin potong krupuk bekerja dengan sumber energi dari motor listrik berkekuatan 200 watt. Adonan bahan baku krupuk yang telah dimasak dan siap untuk dipotong disekitar mesin tersebut, kemudian dimasukkan kedalam cetakan, baru di beri tekanan, dimana tekanan bisa diatur sesuai dengan ketebalan krupuk yang diinginkan pada saat dipotong.

Ketika tombol on maka mesin siap memotong krupuk setelah itu kerupuk baru dijemur pada sinar matahari atau dengan pengering yang lain.

Gambar 3.4 Skema Mesin Pemotong Kerupuk Rambak Singkong

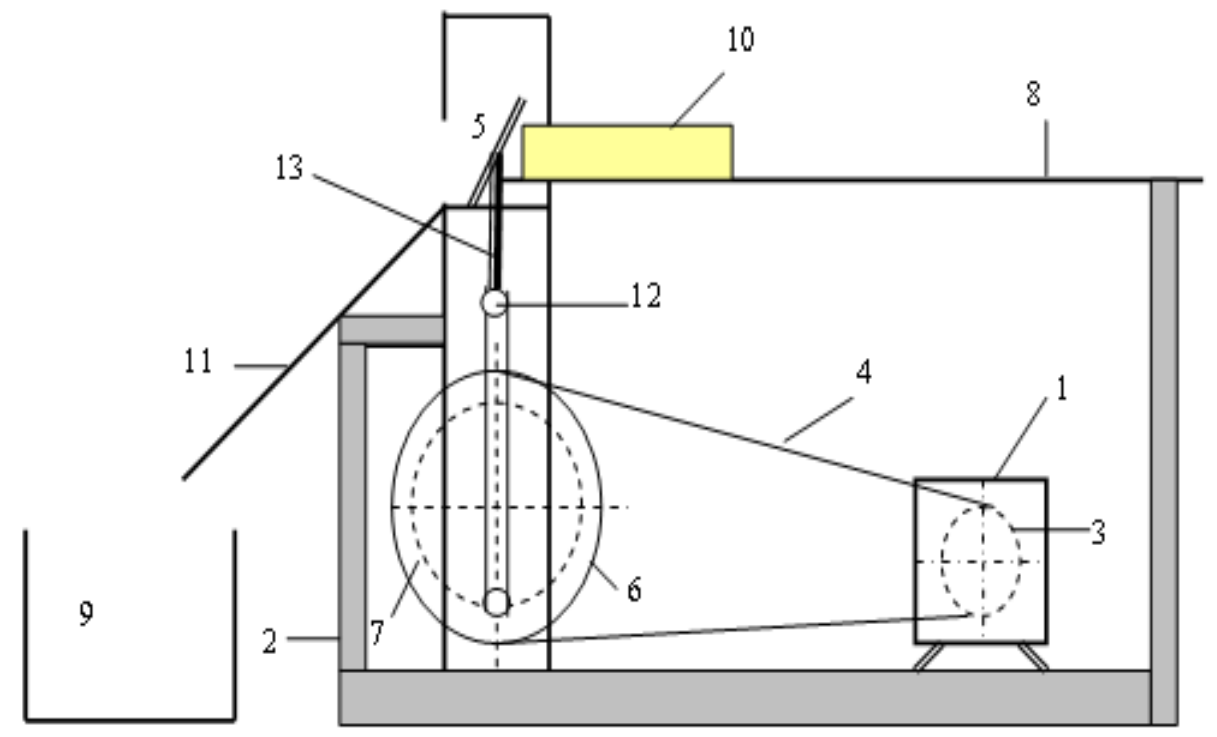




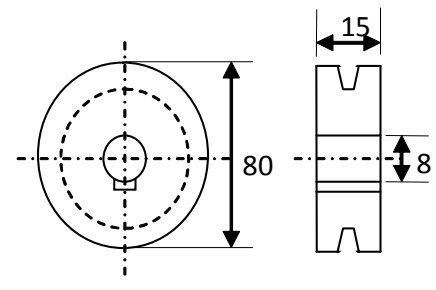

(3) Puly motor listrik

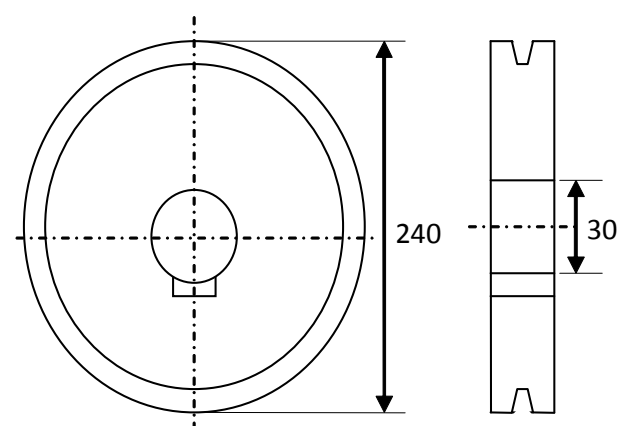

6 Puly penggerak pisau

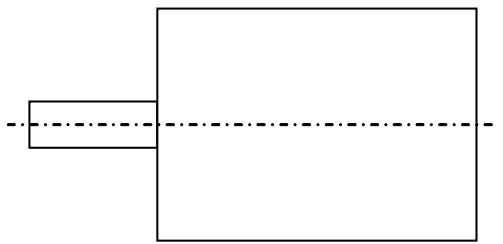

(1) Motor listrik

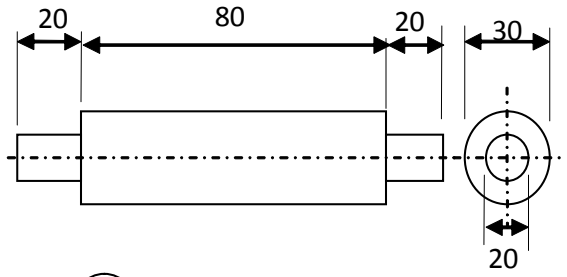

14 Poros puly penggerak

Gambar 3.5 Komponen bagian Mesin Pemotong Kerupuk Rambak Singkong 
Ali Moehtar dkk. Penggunaan Mesin Pemotong Kerupuk Hemat

\begin{tabular}{|c|c|c|c|c|c|c|}
\hline 14 & 1 & \multicolumn{2}{|l|}{ POROS PULYY PENGGERAK } & & \multicolumn{2}{|c|}{ EILC } \\
\hline 13 & 1 & \multicolumn{2}{|l|}{ BATANGPENG PISAU } & & & \\
\hline 12 & 2 & PIN & BESICOR & & & \\
\hline 11 & 1 & \multirow{2}{*}{$\begin{array}{l}\text { TALANGKRUPUK } \\
\text { KRUPUKSEB DIPOIONG }\end{array}$} & BAJA & PLAT & & \\
\hline 10 & 1 & & BAJA & PROFIL L & & \\
\hline 9 & 2 & TEMPATKERUPUKCETAK & PLASTIK & KALENG & & \\
\hline 8 & 1 & LANDASANPEMOIONG & BAJA & PLAT & & \\
\hline 7 & 1 & \multirow{2}{*}{$\begin{array}{l}\text { FLYWELL } \\
\text { PULYPENGGERAKPISAU }\end{array}$} & BESI COR & & & \\
\hline 6 & 2 & & BESICOR & & & \\
\hline 5 & 1 & PISAUPOIONG & BESI CARBON & HSS & & \\
\hline 4 & 2 & VBELT & KARETDANSERAT & TYPEA & & \\
\hline 3 & 5 & PULYMOIOR & BESICOR & PULYMOIOR & & \\
\hline 2 & 1 & RANGKA & BAJA & PROFL L & & \\
\hline 1 & 1 & MOIORLISIRIK & $\mathrm{AC} / \mathrm{DC}$ & $200-350 \mathrm{~W}$ & & \\
\hline NO. & $\mathrm{JMLH}$ & NAMABAGIAN & BAHAN & UKURAN & \multicolumn{2}{|c|}{ KEIERANGAN } \\
\hline \multicolumn{2}{|c|}{$\begin{array}{c}\text { KEKASARAN } \\
\mu \mathrm{m}\end{array}$} & TOLERANSI ISO & & & & \\
\hline \multirow{3}{*}{\multicolumn{2}{|c|}{ (1). }} & SKALA $: 1: 2$ & \multicolumn{2}{|c|}{ DIGAMBAR : IR AU MOKHTARMT, } & \multirow{3}{*}{\multicolumn{2}{|c|}{ PERINGATAN }} \\
\hline & & UKURAN :mm & NIP. & & & \\
\hline & & TANGGAL: 8- 2009 & DШHAT & & & \\
\hline \multicolumn{2}{|c|}{ UMM } & \multicolumn{3}{|c|}{ MESINPEMOTONGKRUPUK } & No. 01 & $A_{4}$ \\
\hline
\end{tabular}

\subsection{Kapasitas Mesin}

Mesin ini dirancang hemat energi, karena bahan yang digunakan adalah bahan yang cukup ringan tetapi tetap kuat, sehingga dengan tenaga yang kecilpun cukup kuat untuk memotong bahan adonan krupuk, dan mesin potong ini dirancang dengan kapasitas $40 \mathrm{~kg} / \mathrm{jam}$. Dengan perhitungan bahwa putaran poros pisau potong dirancang $100 \mathrm{rpm}$ (100 putaran tiap menit), karena mata pisau potong ada 1 yang berarti sekali putaran poros pisau mesin dapat memotong 1 kali, setiap menit mesin dapat memotong sebanyak 1 x 100 $=100$ potong krupuk, yang berarti tiap jam mesin dapat memotong sebanyak 100 x 60 $=6000$ potong krupuk.
Ukuran tiap krupuk mempunyai ketebalan $2 \mathrm{~mm}(0,002 \mathrm{~m})$, diameter 60 $\mathrm{mm}(0,060 \mathrm{~m})$ maka volume tiap krupuk $=\mathrm{t} \times \pi \times \mathrm{r}^{2}=0,002 \times 3,14 \times 0,03^{2}=$ $0,000005652 \mathrm{~m}^{3}$, dalam satu menit mesin mampu memotong $100 \times 0,000005652 \mathrm{~m}^{3}$ $=0,0005652 \mathrm{~m}^{3}$ sehingga dalam satu jam mampu memotong sebanyak $60 \mathrm{x}$ $0,0005652 \mathrm{~m}^{3}=0,0339 \mathrm{~m}^{3}$, jika berat jenis krupuk siap dipotong sebesar $1200 \mathrm{~kg} / \mathrm{m}^{3}$ maka kapasitas potong mesin sebesar 1200 $\mathrm{kg} / \mathrm{m}^{3} \times 0,0339 \mathrm{~m}^{3}=40,6944 \mathrm{~kg}$ atau sekitar $40 \mathrm{~kg} / \mathrm{jam}$, jika satu hari mesin potong beroperasi 5 jam maka kapasitas potong menjadi $200 \mathrm{~kg} / \mathrm{hari}$, sehingga dalam satu bulan mampu memproduksi $6000 \mathrm{~kg}$ atau 6 ton tiap bulan. 


\subsection{Effisiensi Kerja Mesin}

Jika pekerjaan memotong krupuk itu dikerjakan dengan tenaga manusia membutuhkan sekitar 6 orang selama 6 jam untuk memotong adonan krupuk sebanyak $40 \mathrm{~kg}$, maka dengan menggunakan mesin ini hanya membutuhkan waktu satu jam dalam memotong krupuk sebayak $40 \mathrm{~kg}$ adonan dengan tenaga cukup 2 orang, dan jika mesin bekerja selama 6 jam maka akan menghasilkan $240 \mathrm{~kg}$.

Sehingga dengan menggunakan mesin pemotong ini dari segi waktu saja bisa menghemat 5 jam dan dari segi tenaga bisa menghemat 4 orang tenaga. Adapun dari segi waktu jika pemotongan dilakukan dengan mesin ini effisiensi bisa mencapai $=5 \times(100: 6)=83 \%$, sedangkan dari tenaga dengan menggunakan mesin effisiensi tenaga kerja bisa mencapai $=4 \mathrm{x}$ $(100: 6)=66,7 \%$ dibanding dengan menggunakan tenaga manusia.

\section{Tujuan Ptrogram}

Tujuan program kegiatan Vucer ini adalah :

1. Memberikan teknologi tepat guna yang mudah diterapkan berupa mesin yang pencetak kerupuk hemat energi, sehingga mampu meningkatkan produksi dan kualitas kerupuk rambak singkong.

2. Meningkatkan kapasitas produksi kerupuk rambak singkong menjadi 5-6 ton/bulan.

3. Meningkatkan efisiensi kerja (dapat dikerjakan dengan 1 orang saja), sehingga tenaga kerja dapat dialihkan untuk kegaiatn lain.
4. Meningkatkan pendapatan UKM (dari pendapatan bersih $500 \mathrm{ribu} /$ bulan/kwintal menjadi 3 juta / bulan/kwintal).

5. Meningkatkan kualitas krupuk (lebih higienis atau tidak terkontaminasi oleh mikroba yang menempel pada tangan pekerja).

\section{Manfaat Program}

Manfaat kegiatan vucer ini adalah sebagai berikut.

\section{Potensi Ekonomis Produk}

Keuntungan secara ekonomi apabila proses pencetakan dilakukan dengan menggunakan mesin pencetak kerupuk maka penghasilan akan meningkat $600 \%$ karena meningkatnya kapasitas produksi dari 1 ton/bulan menjadi 6 ton/bulan. Kualitas kerupuk rambak singkong lebih terjamin dan terhindar dari kontaminasi jamur/bakteri.

\section{Nilai Tambah Produk dari Sisi Iptek} Penggunaan mesin pencetak ini sangat efektif dan efisien, karena dapat menekan biaya pencetakan karena hanya menggunakan 1 tenaga operator dan waktu pencetakan lebih singkat yaitu 40 kg hanya dalam waktu 1 jam. Dengan demikian akan meningkatkan kapasitas produksi kerupuk rambak singkong menjadi 6 ton/bulan. Sedangkan nilai tambah sisi iptek yang dapat diperoleh bagi perguruan tinggi adalah:

a. Penerapan teknologi mesin pencetak kerupuk hemat energi.

b. Penggunaan teknologi yang praktis, murah dan mudah diterapkan oleh UKM mitra 
c. Kerjasama Fakultas Teknik dengan UKM sebagai tempat aplikasi hasil penelitian dalam pemanfaatan mesin pencetak kerupuk hemat energi dalam upaya meningkatkan produksi dan kualitas kerupuk rambak singkong.

3. Dampak Sosial Secara Nasional

a. Dampak sosial secara mikro adalah meningkatakan pendapatan dan kesejahteraan UKM mitra. Pendekatan yang dilakukan adalah melaui penerapan teknologi penggunaan mesin pencetak kerupuk hemat energi.

b. Dampak sosial secara makro pengabdian melalui program vucer ini adalah:

Tercapainya efisiensi usaha baik dalam produktivitas pencetakan kerupuk maupun untuk pengusaha kerupuk akan menghemat biaya produksi.

Semakin luasnya ketersediaan lapangan kerja atau alternatif berusaha, khususnya pemasaran kerupuk rambak singkong.

Memacu kegiatan usaha, baik untuk usaha pembuatan kerupuk, bengkel mesin pencetak kerupuk maupun usaha pemasaran kerupuk.

Transfer teknologi untuk meningkatkan kualitas sumber daya manusia di pedesaan.

\section{PELAKSANAAN KEGIATAN}

\section{Realisasi PenyelesaiaMasalah}

Realisasi penyelesaian masalah yang kami lakukan yaitu dengan mengetahui kondisi UKM yang ada serta fasilitas yang ada pada Perguruan Tinggi, baru dapat merancang atau mendesain mesin pencetak krupuk tersebut sehingga dapat dikerjakan didalam bengkel yang ada. Dalam pelaksanaannya UKM merasa sangat terbantu dengan adanya program ini, bahkan meminta untuk menindaklanjuti ke program-prograk berikutnya, terutama sesuai saran - saran dari monev yaitu tentang proses pengeringan dan proses pengemasan, sehingga akan didapatkan hasil akhir yang mampu bersaing dengan produk yang sejenis.

\section{Sumber Daya Manusia Perguruan Tinggi}

\begin{tabular}{|l|l|l|l|l|}
\hline No & Nama Lengkap & Pekerjaan & Bidang Keahlian & Tugas dalam Vucer \\
\hline 1. & Ali Mokhtar, Ir.,MI. & Dosen & Teknik Mesin & Ketua \\
2. & DR. Agus Kresno, MKes. & Dosen & Imu Gizi & Anggota \\
3. & Sumardi & Srrasta & Tani & Níta \\
\hline
\end{tabular}

\section{Metode yang di Gunakan}

Untuk meningkatkan kapasitas produksi dan kualitas kerupuk rambak singkong, maka perlu alat pencetak kerupuk. Adapun kerangka penyelesaian masalah secara skematis terlihat pada gambar. Metode yang digunakan dalam program ini adalah pelatihan penggunaan mesin pencetak kerupuk, pembinaan dan pendampingan UKM serta bantuan alat pencetak kerupuk. Pelatihan memberikan bekal kepada UKM tentang teknik pengoperasian, dan perbaikan mesin. Pembinaan dan pendampingan sebagai kaji tindak agar UKM mitra mampu menggunakan mesin pencetak secara mandiri setelah mengikuti pelatihan. 


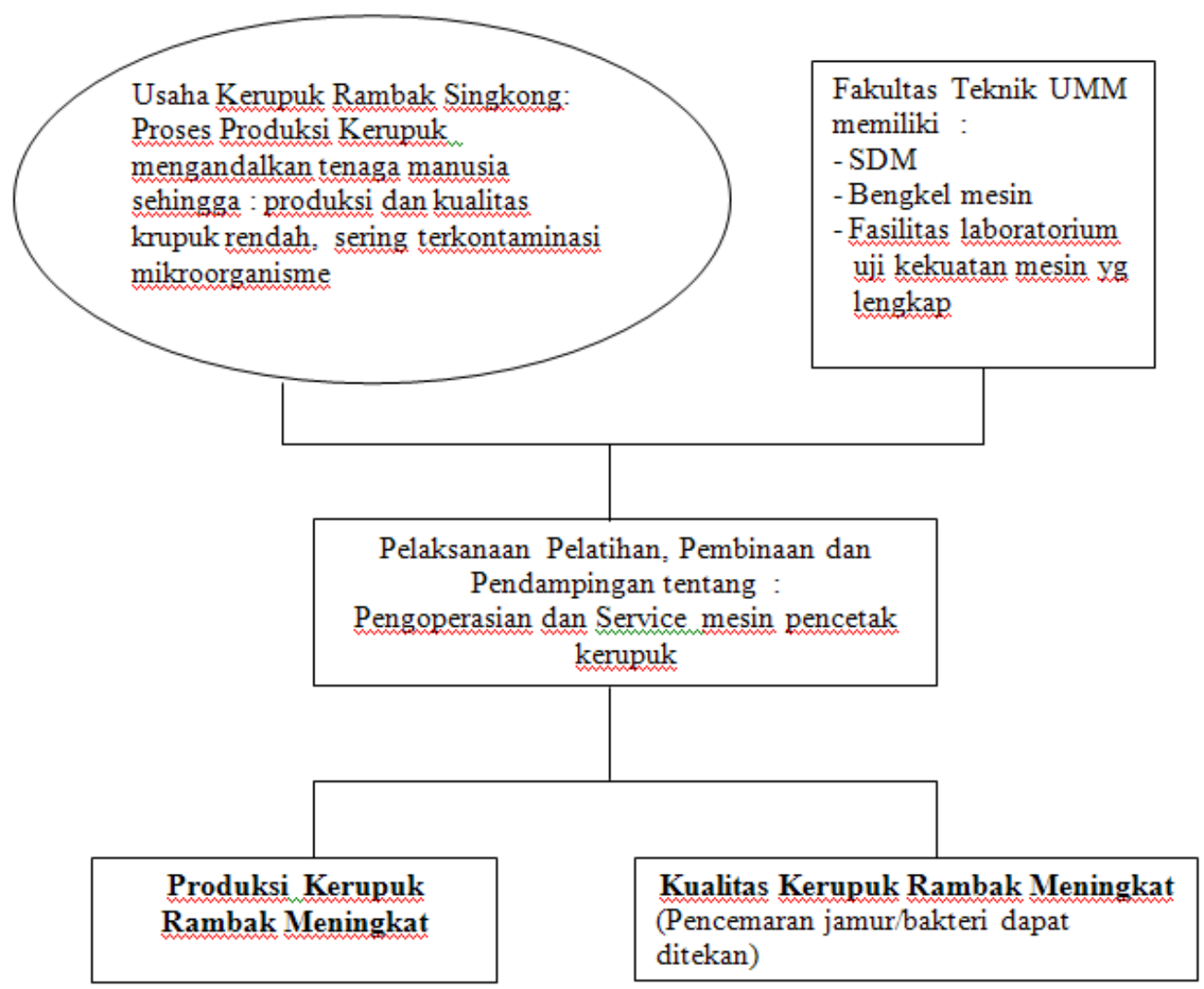

Gambar 5.1 Skema Metode Pelaksanaan Program 


\section{KESIMPULAN DAN SARAN}

\section{Evaluasi Hasil}

Program Vucer ini sangat bermanfaat sekali untuk kalangan UKM dan juga untuk Perguruan Tinggi, oleh karena itu program ini harus diteruskan sehingga dapat menumbuhkan industriindustri pemula.

Evaluasi hasil yang kami lakukan dapat di rangkum sebagai berikut :

a. UKM mitra sangat senang dengan bantuan program vucer ini

b. UKM. mitra dapat meningkatkan penghasilannya

c. UKM. mitra dapat mengembangkan usaha dan memperluas marketing

d. UKM. mitra dapat memenuhi kebutuhan konsumen

e. UKM. mitra dapat mengembangkan diri dengan pelatihan-pelatihan dan mesin yang telah diberikan, sehingga dapat memperbesar usaha dan membeli mesin sendiri yang lebih besar kapasitasnya.

Faktor Pendorong program vucer ini antara lain : UKM. Mendapat pelatihan-pelatihan dan sumbangan mesin secara gratis, permintaan krupuk rambak meningkat pesat, konsumen cukup besar.

Faktor Penghambat diantaranya kurangnya tepat jadwal saat pemberian dana sehingga penyelesainnya juga agak terlambat, jumlah dana yang diberikan cukup minim sehingga tidak dapat membuat mesin berkapasitas besar.

Berikut ini adalah foto-foto hasil kegiatan produksi kerupuk di UKM UD KERUPUK ENAK, di Desa Druju Kab. Malang.

\section{Kesimpulan}

Setelah kami melakukan Program Vucer ini maka dapat kami simpulkan sebagai berikut :
a. UKM mitra sangat senang dengan bantuan program vucer ini
b. UKM. dapat meningkatkan kapasitas produksi yang semula dengan alat manual hanya mampu memproduksi 2 ton tiap bulan, dengan bantuan alat ini dapat memproduksi 5 sampai 6 ton tiap bulan.
c. Pendapatan UKM mitra meningkat, yang semula satu bulan hanya 5 juta, dengan menggunakan mesin bisa 30 juta.
d. UKM. Dapat memenuhi kebutuhan konsumen sehingga tidak perlu menolak konsumen untuk mendapatkan krupuk rambak.
e. UKM. Dapat mengembangkan diri dengan pelatihan-pelatihan dan mesin yang telah diberikan, sehingga dapat memperbesar usaha dan membeli mesin sendiri yang lebih besar kapasitasnya.

\section{Saran.}

Setelah kami melakukan Program Vucer ini maka dapat kami berikan saran sebagai berikut :

a. Sebaiknya jadwal pengucuran dana tepat waktu, sehingga program tidak molor 
Jurnal Dedikasi Volume 7, Mei 2010

b. Sebaikknya jumlah dana di naikkan mengingat semua harga peralatan dan bahan baku naik drastis.

c. Sebaiknya jumlah dana juga jangan disamakan, dengan mempertimbangkan mesin yang akan dibuat serta sejauh mana manfaatnya.

d. Sebaiknya semua usulan didanai semua, dengan sarat di site visit dahulu.

e. Sebaiknya bantuan dari pemerintah diwujudkan dalam bentuk program-program seperti ini, untuk mengurangi kebocoran - kebocoran.

\section{Daftar Pustaka}

Kiyokatsu Suga, Sularso, 1991. Dasar Perencanaan dan Pemilihan Elemen Mesin. Jakarta: Swakarya.

Mitra Wacana, 2008-a. Info Usaha:

Menangguk Rezeki dari Kerupuk, http:// www. wacanamitra.com/ wmi20/ infousaha.htm, diakses 24 Maret 2008. Mitra Wacana, 2008-b. Info Usaha: Regenerasi Pengusaha Kerupuk, http:// www. wacanamitra.com/wmi20/ infousahab.htm, diakses 24 Maret 2008. Mesin Industri. Com, 2008. Mesin Pencetak Kerupuk, http:// www.mesinindustri. com /Mesin, diakses, 24 Maret 2008

PT Toko Mesin Maksindo, 2008. Alat dan Mesin Pembuat dan Pencetak Kerupuk, http://www.tokomesin.com/ Mesin_Pengolah_Kerupuk, diakses, 24 Maret 2008
Ranald V. And Giles, B.S., M.S, 1992. Fluid

Mechanics and Hydraulics. New York:

McGraw-Hill, Inc.

\section{Lampiran}
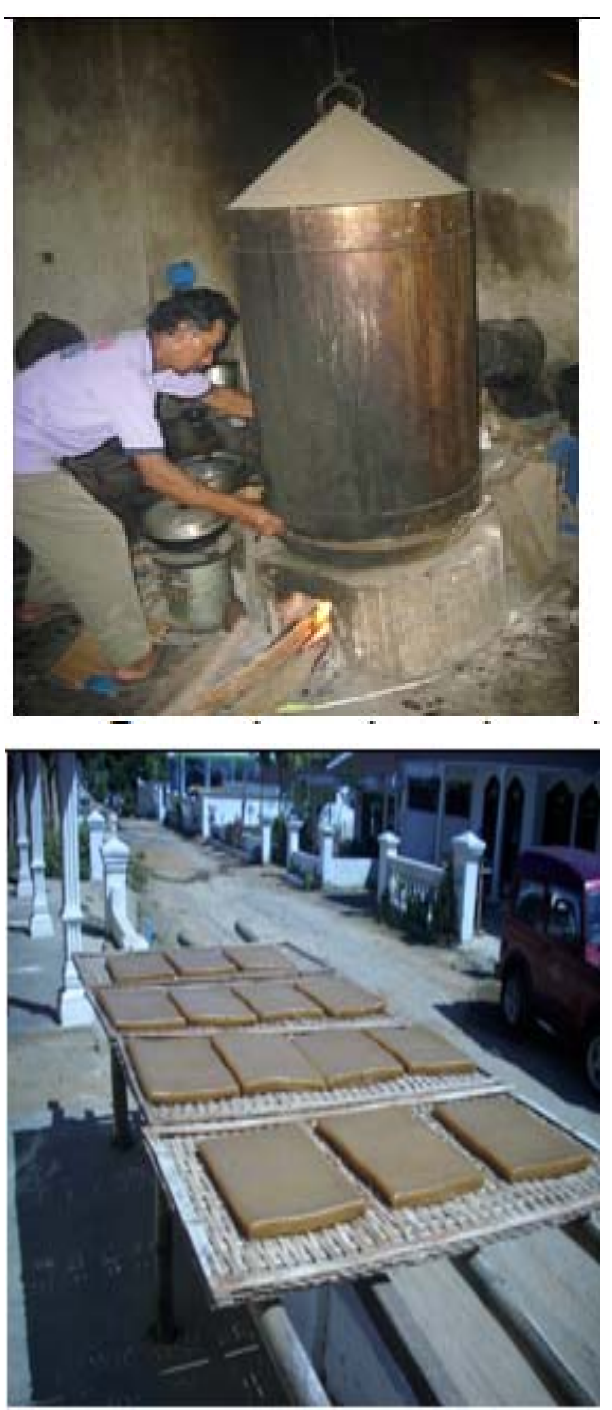
Ali Moehtar dkk.Penggunaan Mesin Pemotong Kerupuk

Hemat
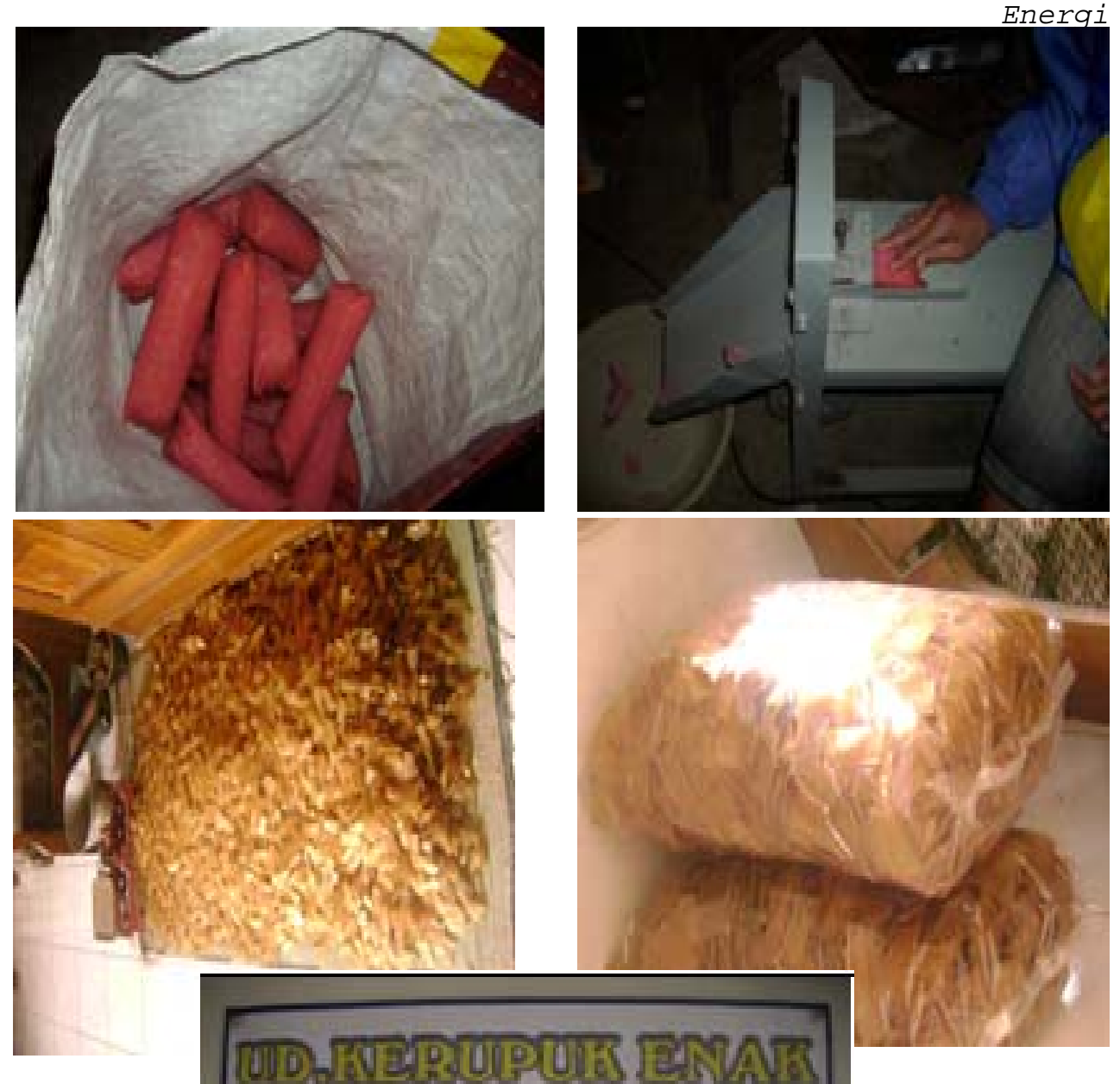

RT. 1 RW. 1 Ds. DRUJU

KEC. SUMBERMANJINO WETAN KAB. MALANO

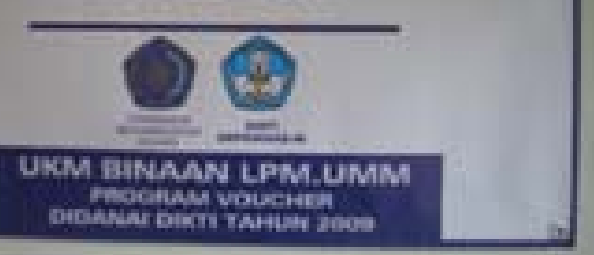


Jurnal Dedikasi Volume 7, Mei 2010 